\title{
Petrochemical Characterization of Two Distinct Types of Dolerites from Bafoussam Area, West Cameroon
}

\author{
Gus Djibril Kouankap Nono ${ }^{1,2^{*}}$, Pierre Wotchoko ${ }^{1}$, Sylvestre Ganno ${ }^{2 *}$, Divine Ngong Njinchuki ${ }^{2}$, \\ Jean Paul Nzenti ${ }^{2}$, Cheo Emmanuel Suh ${ }^{3}$ \\ ${ }^{1}$ Department of Geology, HTTC, University of Bamenda, Bamenda, Cameroon \\ ${ }^{2}$ Laboratory of Petrology and Structural Geology, Faculty of Science, University of Yaoundé I, Yaoundé, Cameroon \\ ${ }^{3}$ Economic Geology Unit, Department of Geology, University of Buea, Buea, Cameroon \\ Email: kouankap@yahoo.fr, sganno2000@yahoo.fr
}

Received August 7, 2013; revised September 8, 2013; accepted September 29, 2013

Copyright (C) 2013 Gus Djibril Kouankap Nono et al. This is an open access article distributed under the Creative Commons Attribution License, which permits unrestricted use, distribution, and reproduction in any medium, provided the original work is properly cited.

\begin{abstract}
Two petrochemical types of doleritic dykes have been distinguished in Bafoussam area: 1) the olivine-bearing dolerites which are the most representative are dark green, showing characteristics of alkaline basalts and, 2) the calcite-bearing dolerites are grayish green, showing characteristics of tholeiitic basalts. The studied dolerites are less differentiated $(1<$ $\mathrm{FeO}^{\mathrm{t}} / \mathrm{MgO}<2$ ); they present the evolution of a subalkaline magma following a calc-alkaline series (alkaline dolerites) and the tholeiitic series (tholeitiic dolerite). The chondrite normalized multielement spider diagrams of all the dolerites show a pronounced depletion in $\mathrm{Ba}, \mathrm{Th}$, and enrichment in $\mathrm{Rb}$. Their geotectonic context is inferred to be intraplate and the contrast between the two types is probably due to a diverse source: crustal source for calcite-bearing dolerites and mantle source for olivine-bearing dolerites.
\end{abstract}

Keywords: Doleritic Dyke; Petrochemical; Alkaline; Tholeiitic; Intraplaque; Bafoussam

\section{Introduction}

The West Cameroon region constitutes an integral part of two major structures that make up the geology of Cameroon: the Cameroon Volcanic Line (CVL) and the Central Cameroon Shear Zone (CCSZ). The relations between these two structures have already been the subject of many scientific works [1-4]. The CCSZ, which is an assemblage of branching and coalescing faults, controls the emplacement of granitoid massifs during the Panafrican orogeny [5-7].

The Banefo-Mvoutsaha area comprises two lithological sets: 1) tertiary volcanic formations and 2) graniticgneissic Precambrian units. The latter are overlain by the volcanics, in this case dolerite. In Cameroon, doleritic magmatism is poorly reported. The few data available are those on dolerite dykes observed in cratonic formations of southern Cameroon [8] and in Adamawa region, North Cameroon [9], and the recent work on basaltic dyke swarms from southern part of Cameroon Volcanic Line [10]. No scientific works have been carried out on the dolerite dykes intruded into Panafrican rocks in western

${ }^{*}$ Corresponding authors.
Cameroon. In this paper, we present the first data of the Banefo-Mvoutsaha dolerites including detailed petrographic and geochemical studies with the aim of characterizing the source of magma, their evolution and geotectonic context. Aspects of metallogeny are also presented considering that the study area forms part of a major shear zone; a potential zone for hydrothermal mineralization.

\section{Geological Setting and Previous Work}

The Banefo-Mvoutsaha area is located along the Cameroon Volcanic Line CVL (Figure 1) which is a megastructure in central Africa oriented $\mathrm{N} 30^{\circ} \mathrm{E}$ and extending $\sim 2000 \mathrm{~km}$ in a length and $100 \mathrm{~km}$ in width. The CVL extends from the island of Pagalu in the Gulf of Guinea to Lake Chad [11-14]. Magmatism commenced here towards the end of Cretaceous and few volcanic centres are still active [15]. The study area is also located in the central domain of the Panafrican North Equatorial Belt (PNEB) in Cameroon (Figure 1). The PNEB or Central African Orogen is a major Neoproterozoic Orogen linked to the Trans-Saharan Belt of western Africa and to the 


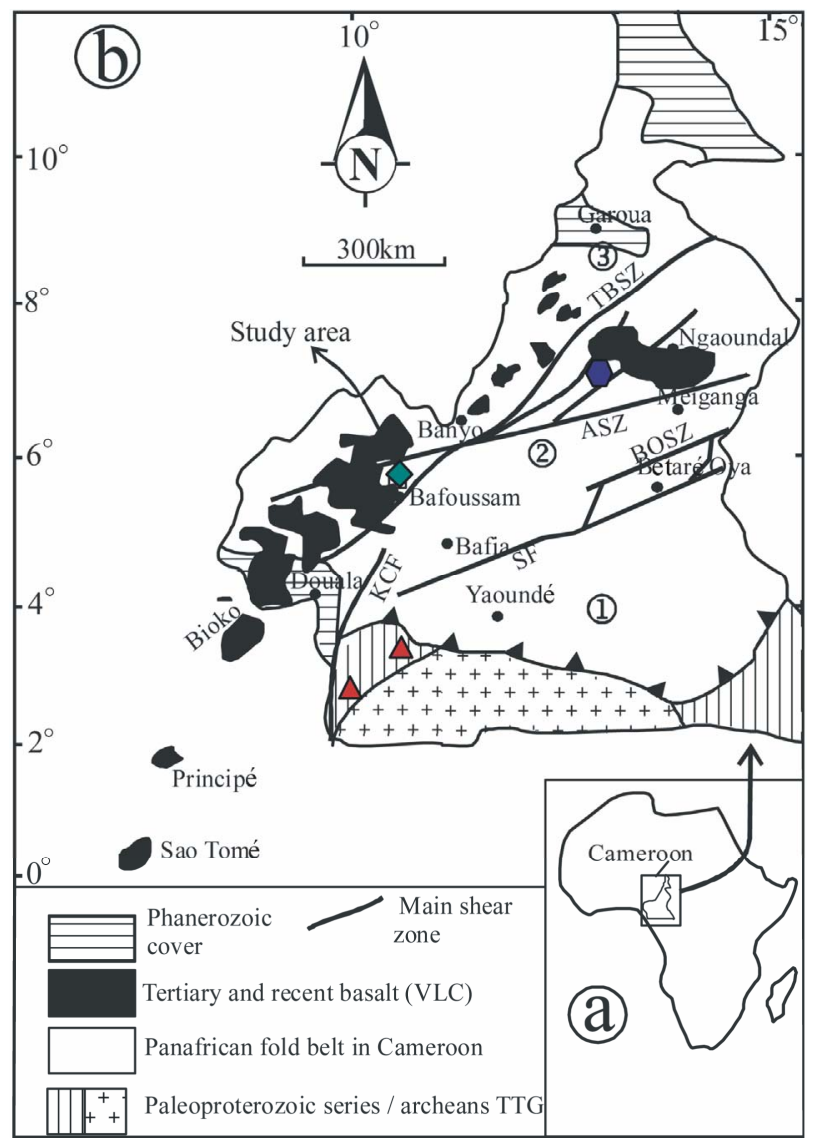

Figure 1. Simplified geological map of Cameroon showing the main lithological domains, the Cameroon volcanic line and the location of known dolerite occurrence (filled triangles: dolerite studied by [8]; filled hexagon: dolerite studied by [9]; filled losange: dolerite studied in this work).

Brasiliano Orogen of NE Brazil. The principal characteristics of the PNEB in Cameroon have been presented in earlier works, e.g. [16-23]. The PNEB, which is partly covered by basalts and trachytes of Tertiary to Recent age, is constituted by metamorphic and magmatic assemblages related to tectono-metamorphic events of the Panafrican orogeny. In this belt, three geodynamic domains have been distinguished: 1) a North Cameroon domain; 2) a Central Cameroon domain; 3) a South Cameroon domain (Figure 1).

The central Cameroon domain, to which this study area belongs, constitutes a link between the northern part and the southern part of the belt. It is marked by multiple intrusions of Panafrican granitoids in which their emplacement is controlled by major strike-slip faults, notably the Central Cameroon Shear Zone (CCSZ) that has an $\mathrm{N} 70^{\circ} \mathrm{E}$ trend.

In the Ntem group (South Cameroon), Vicat et al. [8] described two distinct episodes $\left(\mathrm{D}_{1}\right.$ and $\left.\mathrm{D}_{2}\right)$ of dolerite dykes intruding the Paleoproterozoic formations of the Congo Craton. The first generation of dolerite dykes in- trusion predated the Eburnean orogeny and their composition is similar to that of tholeiites from back arc settings, while the second event succeeded the Panafrican orogeny with the composition of continental tholeiite.

In the Adamawa plateau (North Cameroon), Vicat et al. [9] identified previous alkaline volcanism of dolerites of Cenozoic era along the CVL. The dolerite dykes of the Adamawa plateau have chemical composition of continental tholeiites. According to these authors, these dykes belong to an early phase of continental rifting and the source of the magma is from the contaminated continental lithosphere.

The geology of Bafoussam area (Banefo-Mvoutsaha sector; Figure 2) is made up of three main lithological units [24]: 1) a metamorphic unit made up of garnetbearing gneiss, migmatites and amphibolites; 2) a plutonic rocks unit made up of deformed granitoods with gneissic texture, and 3) a volcanic rocks unit made up of basaltic lavas and dolerite dykes.

\section{Analytical Methods}

Nine representative and fresh samples at the BanefoMvoutsaha (NE Bafoussam), in the Central domain of the Panafrican Belt of Cameroon were investigated in terms of their petrography and whole rock geochemistry. Every effort was made to minimize the potential of crosscontamination of samples and introduction of external contaminants during sample transportation and preparation. These samples were thin sectioned at Geotech Lab (Canada) using conventional techniques. For whole rock geochemical analysis, all the samples required pulverizing to obtain homogeneous samples. After crushing and

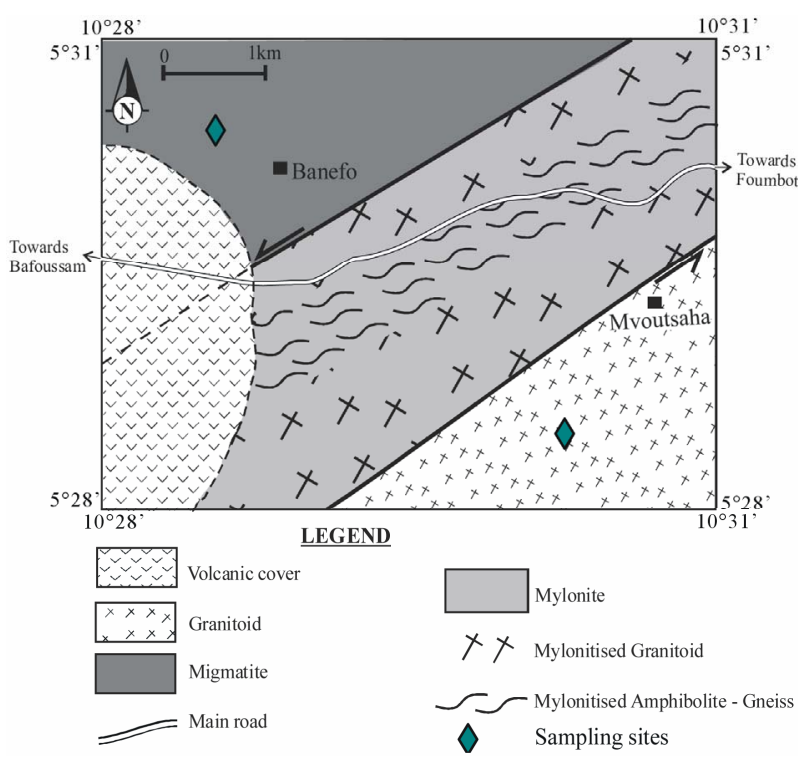

Figure 2. Geological map of Banefo-Mvoutsaha area (after Kouankap Nono et al. [24]) and location of dolerite sampling sites. 
milling, samples were split and 50 - $60 \mathrm{~g}$ of samples was obtained for the analyses. Chemical analysis was done using the pulp at ACME Analytical Laboratories Ltd., Vancouver (Canada) (www.acmelab.com). Whole rock analyses for major and trace elements were carried out by Inductively-oupled Plasma Mass Spectrometry (ICP-MS) from pulps. $0.2 \mathrm{~g}$ of rock powder was fused with $1.5 \mathrm{~g}$ $\mathrm{LiBO}_{2}$ and then dissolved in $100 \mathrm{~mm}^{3} 5 \% \mathrm{HNO}_{3}$. The REE contents were determined by ICP-MS from pulps after 0.25 g rock-powder was dissolved with 4 acid digestions. Analytical uncertainties vary from $0.1 \%$ to $0.04 \%$ for major elements; from $0.1 \%$ to $0.5 \%$ for trace elements; and from 0.01 to $0.5 \mathrm{ppm}$ for rare earth elements. The remaining trace elements were analysed by ICP-MS after $0.5 \mathrm{~g}$ split of sample pulp is digested in aqua regia. Loss on ignition (LOI) was determined by weight difference after ignition at $1000^{\circ} \mathrm{C}$. Various standards were used and data quality assurance was by running these standards between samples as unknowns. Representative geochemical data for the dolerite samples of the Banefo-Mvoutsaha area are listed in Table 1.

\section{Results}

\subsection{Petrography}

The dolerite outcrops as dismantled dykes are in the form of blocks that are centrimentric in size (Figures 3(a) and (e)). They have an average trend of $\mathrm{N} 115^{\circ} \mathrm{E}$, and their hosts are migmatitic gneiss and S-C mylonite. The petrographic study reveals two main types: 1) olivine-bearing dolerite and 2) calcite-bearing dolerite.

\subsubsection{Olivine-Bearing Dolerite}

The olivine-bearing dolerites are massive, compact and present a distinct doleritic texture. Under the microscope, the rock is composed of plagioclase, olivine, pyroxene and opaque minerals (Figures 3(c) and (d)). Crystals of plagioclase show varied sizes $(1-5 \mathrm{~mm} \times 0.5-1 \mathrm{~mm})$ embedded in a dark glassy matrix. Plagioclase microliths are common in the matrix. Olivine crystals are irregular in shape, $\sim 0.24 \mathrm{~mm}$ in size and have matrix glass extending into the numerous fractures on these crystals. The relative abundance of pyroxene is inferior to that of olivine. Their dimensions vary from 1 to $2 \mathrm{~mm}$ and some crystals present a reaction rim. Opaque minerals $(0.1$ $0.2 \mathrm{~mm}$ ) are subhedral and xenomorphic. The matrix constitutes more than $40 \%$ of the rock. The order of crystallization of phenocrysts is as follows: olivine and pyroxene-plagioclase-amphibole-opaque.

\subsubsection{Calcite-Bearing Dolerite}

The calcite-bearing dolerites are massive and appear greenish. The plagioclase grains have varied sizes from 2 to $7 \mathrm{~mm}$ in length $\times 2 \mathrm{~mm}$ in width. The calcite-bearing dolerite presents a typical doleritic texture. The rock is composed of plagioclase, calcite, amphibole and opaques (Figures 3(g) and (h)). The plagioclase phenocrysts are 0.1 to $4 \mathrm{~mm}$ in size. The phenocrysts are less numerous, subhedral and are generally fractured. Some of the crystals are at the earliest stage of weathering. Calcite is the most abundant mineral after the plagioclase. The calcite crystals ( 0.5 to $2 \mathrm{~mm}$ in size) are sub-rounded and are associated with plagioclase and amphiboles. Amphiboles are very rare in the rock and are observed mainly in the rim of calcite. Their crystals are fine in size; most of them constitute the matrix elements. Opaque minerals are rare.

\subsection{Whole Rock Geochemistry}

Geochemical data for the whole rock analysis of selected dolerite samples are presented in Table 1. Using the TAS classification diagram of Le Bas et al. [25], the dolerites plot in the field of subalkaline to tholeiitic basalt (Figure 4). In the $\mathrm{Nb} / \mathrm{Y}$ versus $\mathrm{Zr} / \mathrm{Ti}$ diagram of Pearce [26], the studied dolerites are distributed into two groups. The first group is represented by the basalts and corresponds to the olivine-bearing dolerites, while the second group is represents by the alkaline basalts and corresponds to calcite-bearing dolerites (Figure 5).

\section{- Major elements}

The dolerites have a $\mathrm{SiO}_{2}$ content varying from 46.70 to $49.23 \mathrm{wt} \%$. The olivine-bearing dolerites are more silica-rich $\left(\mathrm{SiO}_{2} \geq 48 \mathrm{wt} \%\right)$. The Harker diagrams showing the variation of major elements versus $\mathrm{MgO}$ (Figure 6) reveals that the two Banefo-Mvoutsaha types of dolerite are well distinguished by their $\mathrm{MgO}$ content. The calcite-bearing dolerites are richer in $\mathrm{MgO}$ with concentrations higher than $7 \mathrm{wt} \%$, while the olivine-bearing dolerite has concentrations lower than $7 \mathrm{wt} \%$. These diagrams show positive correlations with $\mathrm{SiO}_{2}, \mathrm{Fe}_{2} \mathrm{O}_{3}, \mathrm{MnO}$, and $\mathrm{P}_{2} \mathrm{O}_{5}$, no correlations with $\mathrm{TiO}_{2}$ and $\mathrm{Cr}_{2} \mathrm{O}_{3}$, negative correlation with $\mathrm{Na}_{2} \mathrm{O}$ and double correlations with $\mathrm{Al}_{2} \mathrm{O}_{3}$ and $\mathrm{CaO}$ (Figure 6).

The $\mathrm{Na}_{2} \mathrm{O}+\mathrm{K}_{2} \mathrm{O}$ contents of the olivine-bearing dolerites are higher $(4.10 \%-4.23 \%)$ than that of calcite-bearing dolerite $(3.59 \%-3.78 \%)$ and the $\mathrm{K}_{2} \mathrm{O} / \mathrm{Na}_{2} \mathrm{O}$ ratios range from 0.29 to 0.60 (Table 2). In the AFM diagram of Ivrine and Baragar [27], the Banefo-Mvoutsaha dolerites plot into two distinct areas on both sides of the limit between alkaline and tholeiitic fields (Figure 7). The olivine-bearing dolerites belong to the tholeiitic series field and the calcite-bearing dolerites belong to the calc-alkaline series field. This confirms the existence of two distinct types (tholeiitic and calco-alkaline affinities) of dolerite in the study region.

\section{- Trace elements}

The Harker diagrams (Figure 8) of some trace ele- 
Table 1. Geochemical data (assays performed at Acme Lab, Vancouver, Canada) of selected dolerite samples.

\begin{tabular}{|c|c|c|c|c|c|c|c|c|c|}
\hline \multirow{2}{*}{$\begin{array}{l}\text { Rock type } \\
\text { Sample No }\end{array}$} & \multicolumn{6}{|c|}{ Olivine-bearing dolerite } & \multicolumn{3}{|c|}{ Calcite-bearing dolerite } \\
\hline & G14V1 & G14V2 & G14V3 & G14V4 & G14V5 & G14V6 & G14S1 & G14S10 & G14S20 \\
\hline$w t \%$ & 0.43 & 0.23 & 0.52 & 0.19 & 0.20 & 0.23 & 0.24 & 0.51 & 0.69 \\
\hline $\mathrm{SiO}_{2}$ & 46.98 & 46.91 & 46.70 & 46.79 & 46.74 & 47.35 & 48.17 & 48.82 & 49.23 \\
\hline $\mathrm{Al}_{2} \mathrm{O}_{3}$ & 16.08 & 16.61 & 16.59 & 16.46 & 16.12 & 16.84 & 17.08 & 16.71 & 16.62 \\
\hline $\mathrm{Fe}_{2} \mathrm{O}_{3}$ & 11.01 & 11.60 & 11.61 & 12.08 & 12.07 & 11.18 & 10.16 & 10.18 & 10.54 \\
\hline $\mathrm{MgO}$ & 7.55 & 7.15 & 7.33 & 7.25 & 7.21 & 7.20 & 6.56 & 6.14 & 6.23 \\
\hline $\mathrm{CaO}$ & 8.64 & 9.11 & 9.22 & 8.89 & 8.98 & 9.22 & 9.13 & 8.85 & 8.76 \\
\hline $\mathrm{Na}_{2} \mathrm{O}$ & 2.59 & 2.39 & 2.34 & 2.26 & 2.41 & 2.70 & 3.25 & 3.15 & 3.18 \\
\hline $\mathrm{K}_{2} \mathrm{O}$ & 1.00 & 1.31 & 1.30 & 1.36 & 1.28 & 1.08 & 0.93 & 1.08 & 0.92 \\
\hline $\mathrm{TiO}_{2}$ & 1.62 & 1.42 & 1.41 & 1.49 & 1.56 & 1.70 & 1.38 & 1.36 & 1.40 \\
\hline $\mathrm{P}_{2} \mathrm{O}_{5}$ & 0.283 & 0.306 & 0.299 & 0.289 & 0.321 & 0.292 & 0.234 & 0.24 & 0.23 \\
\hline $\mathrm{MnO}$ & 0.16 & 0.17 & 0.17 & 0.18 & 0.18 & 0.17 & 0.14 & 0.13 & 0.14 \\
\hline $\mathrm{Cr}_{2} \mathrm{O}_{3}$ & 0.046 & 0.035 & 0.035 & 0.036 & 0.035 & 0.044 & 0.034 & 0.035 & 0.034 \\
\hline LOI & 3.7 & 2.7 & 2.7 & 2.6 & 2.8 & 1.9 & 2.7 & 3.0 & 2.4 \\
\hline Sum & 99.67 & 99.70 & 99.70 & 99.69 & 99.70 & 99.68 & 99.75 & 99.75 & 99.73 \\
\hline \multicolumn{10}{|l|}{ ppm } \\
\hline $\mathrm{Ba}$ & 613 & 357 & 319 & 396 & 337 & 373 & 271 & 333 & 322 \\
\hline $\mathrm{Be}$ & $<1$ & $<1$ & $<1$ & $<1$ & $<1$ & 2 & 1 & $<1$ & $<1$ \\
\hline $\mathrm{Co}$ & 42.9 & 47.6 & 46.6 & 46.7 & 50.8 & 45.8 & 42.0 & 38.3 & 39.9 \\
\hline Cs & 3.8 & 6.1 & 6.9 & 7.7 & 6.7 & 9.6 & 1.0 & 1.7 & 0.8 \\
\hline $\mathrm{Ga}$ & 17.4 & 17.0 & 17.5 & 18.0 & 19.1 & 19.2 & 17.5 & 17.7 & 17.6 \\
\hline $\mathrm{Hf}$ & 3.9 & 3.4 & 3.2 & 3.6 & 4.3 & 4.0 & 2.8 & 2.6 & 2.7 \\
\hline $\mathrm{Nb}$ & 11.8 & 8.0 & 8.5 & 9.1 & 13.4 & 13.2 & 14.6 & 14.4 & 14.8 \\
\hline $\mathrm{Rb}$ & 56.2 & 159.7 & 159.1 & 174.1 & 168.8 & 85.1 & 19.0 & 35.8 & 22.2 \\
\hline $\mathrm{Sn}$ & $<1$ & $<1$ & $<1$ & 1 & 1 & 1 & 1 & $<1$ & $<1$ \\
\hline $\mathrm{Sr}$ & 362.9 & 340.1 & 343.3 & 332.6 & 340.2 & 387.6 & 466.8 & 460.6 & 449.0 \\
\hline $\mathrm{Ta}$ & 0.6 & 0.4 & 0.5 & 0.5 & 0.9 & 0.8 & 0.8 & 0.9 & 0.9 \\
\hline Th & 1.1 & 0.9 & 0.9 & 1.1 & 1.2 & 1.4 & 1.5 & 1.4 & 1.6 \\
\hline $\mathrm{U}$ & 0.2 & 0.1 & 0.1 & 0.2 & 0.3 & 0.3 & 0.4 & 0.4 & 0.4 \\
\hline $\mathrm{V}$ & 204 & 172 & 170 & 184 & 193 & 213 & 166 & 168 & 169 \\
\hline W & $<0.5$ & $<0.5$ & $<0.5$ & $<0.5$ & $<0.5$ & $<0.5$ & $<0.5$ & $<0.5$ & $<0.5$ \\
\hline $\mathrm{Zr}$ & 166.2 & 130.8 & 134.0 & 141.2 & 171.0 & 182.4 & 110.7 & 108.3 & 107.7 \\
\hline $\mathrm{Y}$ & 28.8 & 28.0 & 25.8 & 28.0 & 31.7 & 33.9 & 18.2 & 17.8 & 17.4 \\
\hline $\mathrm{La}$ & 19.9 & 12.4 & 15.3 & 18.1 & 15.8 & 17.5 & 14.1 & 14.3 & 14.0 \\
\hline $\mathrm{Ce}$ & 33.6 & 26.0 & 27.2 & 28.6 & 35.6 & 36.8 & 29.0 & 29.1 & 29.0 \\
\hline $\operatorname{Pr}$ & 5.06 & 3.89 & 3.92 & 4.15 & 5.22 & 5.72 & 3.94 & 3.95 & 3.88 \\
\hline $\mathrm{Nd}$ & 24.6 & 18.6 & 18.4 & 18.9 & 24.3 & 26.0 & 15.8 & 16.4 & 17.5 \\
\hline $\mathrm{Sm}$ & 5.17 & 4.36 & 4.41 & 4.69 & 5.61 & 5.95 & 3.70 & 3.55 & 3.50 \\
\hline $\mathrm{Eu}$ & 1.74 & 1.55 & 1.51 & 1.59 & 1.69 & 1.82 & 1.25 & 1.22 & 1.17 \\
\hline $\mathrm{Gd}$ & 5.75 & 5.16 & 5.04 & 5.46 & 6.06 & 6.45 & 3.69 & 3.72 & 3.59 \\
\hline $\mathrm{Tb}$ & 0.97 & 0.88 & 0.86 & 0.92 & 1.02 & 1.10 & 0.61 & 0.60 & 0.60 \\
\hline Dy & 5.41 & 5.15 & 4.93 & 5.21 & 5.62 & 6.12 & 3.38 & 3.26 & 3.18 \\
\hline Но & 1.14 & 1.05 & 1.03 & 1.03 & 1.16 & 1.27 & 0.66 & 0.64 & 0.64 \\
\hline $\mathrm{Er}$ & 3.11 & 2.80 & 2.63 & 2.87 & 3.22 & 3.31 & 1.88 & 1.66 & 1.76 \\
\hline $\mathrm{Tm}$ & 0.47 & 0.42 & 0.41 & 0.45 & 0.48 & 0.53 & 0.28 & 0.27 & 0.28 \\
\hline $\mathrm{Yb}$ & 2.83 & 2.55 & 2.41 & 2.49 & 3.05 & 3.19 & 1.60 & 1.54 & 1.56 \\
\hline $\mathrm{Lu}$ & 0.43 & 0.39 & 0.38 & 0.39 & 0.44 & 0.48 & 0.24 & 0.22 & 0.23 \\
\hline Mo & 1.0 & 1.0 & 1.1 & 1.0 & 0.9 & 0.7 & 1.3 & 0.9 & 1.0 \\
\hline
\end{tabular}


Continued

\begin{tabular}{|c|c|c|c|c|c|c|c|c|c|}
\hline $\mathrm{Cu}$ & 42.2 & 69.1 & 66.1 & 68.6 & 67.2 & 46.9 & 59.9 & 56.2 & 56.4 \\
\hline $\mathrm{Pb}$ & 1.2 & 1.5 & 1.7 & 1.6 & 1.5 & 1.4 & 1.3 & 1.1 & 1.4 \\
\hline $\mathrm{Zn}$ & 46 & 63 & 65 & 63 & 61 & 67 & 50 & 40 & 46 \\
\hline $\mathrm{Ni}$ & 28.2 & 64.2 & 59.4 & 63.3 & 54.8 & 37.1 & 76.7 & 62.6 & 69.2 \\
\hline As & $<0.5$ & $<0.5$ & $<0.5$ & $<0.5$ & 0.6 & $<0.5$ & $<0.5$ & $<0.5$ & $<0.5$ \\
\hline $\mathrm{Cd}$ & 0.2 & 0.2 & $<0.1$ & 0.2 & 0.2 & 0.1 & $<0.1$ & 0.1 & $<0.1$ \\
\hline $\mathrm{Sb}$ & $<0.1$ & $<0.1$ & $<0.1$ & $<0.1$ & $<0.1$ & $<0.1$ & $<0.1$ & $<0.1$ & $<0.1$ \\
\hline $\mathrm{Bi}$ & $<0.1$ & $<0.1$ & $<0.1$ & $<0.1$ & $<0.1$ & $<0.1$ & $<0.1$ & $<0.1$ & $<0.1$ \\
\hline $\mathrm{Ag}$ & $<0.1$ & $<0.1$ & $<0.1$ & $<0.1$ & $<0.1$ & $<0.1$ & $<0.1$ & $<0.1$ & $<0.1$ \\
\hline $\mathrm{Au}$ & 2.1 & 1.2 & 1.2 & 0.6 & 1.2 & $<0.5$ & $<0.5$ & $<0.5$ & $<0.5$ \\
\hline $\mathrm{Hg}$ & $<0.01$ & $<0.01$ & $<0.01$ & $<0.01$ & $<0.01$ & $<0.01$ & $<0.01$ & $<0.01$ & $<0.01$ \\
\hline $\mathrm{Tl}$ & 0.5 & 0.6 & 0.6 & 0.8 & 0.5 & 0.6 & $<0.1$ & $<0.1$ & $<0.1$ \\
\hline $\mathrm{Se}$ & $<0.5$ & $<0.5$ & 0.7 & $<0.5$ & $<0.5$ & $<0.5$ & $<0.5$ & $<0.5$ & $<0.5$ \\
\hline$\sum \mathrm{REE}$ & 365.58 & 291.29 & 300.23 & 324.78 & 358.35 & 383.53 & 252.09 & 249.75 & 249.96 \\
\hline$(\mathrm{Ce} / \mathrm{Sm}) \mathrm{N}$ & 1.57 & 1.44 & 1.49 & 1.47 & 1.53 & 1.49 & 1.89 & 1.98 & 2.00 \\
\hline$(\mathrm{La} / \mathrm{Yb}) \mathrm{N}$ & 4.75 & 3.28 & 4.29 & 4.91 & 3.50 & 3.70 & 5.95 & 6.27 & 6.06 \\
\hline$(\mathrm{Gd} / \mathrm{Yb}) \mathrm{N}$ & 1.64 & 1.64 & 1.69 & 1.77 & 1.61 & 1.63 & 1.86 & 1.95 & 1.86 \\
\hline$(\mathrm{Gd} * \mathrm{Sm}) \mathrm{N}$ & 944.86 & 715.07 & 706.45 & 813.91 & 1080.55 & 1219.80 & 433.95 & 419.74 & 399.37 \\
\hline$(\mathrm{La} / \mathrm{Lu}) \mathrm{N}$ & 4.80 & 3.30 & 4.18 & 4.82 & 3.73 & 3.78 & 6.10 & 6.75 & 6.32 \\
\hline$(\mathrm{La} / \mathrm{Sm}) \mathrm{N}$ & 2.42 & 1.79 & 2.18 & 2.43 & 1.77 & 1.85 & 2.40 & 2.54 & 2.52 \\
\hline$(\mathrm{Gd} / \mathrm{Lu}) \mathrm{N}$ & 1.66 & 1.64 & 1.65 & 1.74 & 1.71 & 1.67 & 1.91 & 2.10 & 1.94 \\
\hline $\mathrm{Eu} / \mathrm{Eu}^{*}$ & 0.98 & 1.00 & 0.98 & 0.96 & 0.89 & 0.90 & 1.03 & 1.03 & 1.01 \\
\hline
\end{tabular}

N.B: $\sum$ REE is calculated without include the values of $\mathrm{Y}$ element which is sometimes considered as REE for his ionic radius similar of the REE Ho.

ments plotted versus $\mathrm{MgO}$ reveal the existence of two groups of dolerites in Banefo-Mvoutsaha area. These diagrams show positive correlations between ${ }^{*}$ state the element ${ }^{*}$ with $\mathrm{Rb}, \mathrm{Zr}, \mathrm{Zn}, \mathrm{Y}$ and $\mathrm{Y}+\mathrm{Nb}$, no correlation with $\mathrm{Ba}$, negative correlations with $\mathrm{Nb}, \mathrm{Ni}$ and $\mathrm{Sr}$ and positive and negative correlations with Co. The values of the different ratios of some trace elements (Table 2) also underline the existence of two distinct groups of dolerites. The $\mathrm{Ba} / \mathrm{Rb}, \mathrm{Ce} / \mathrm{Yb}$ and $\mathrm{Sm} / \mathrm{Yb}$ ratios are more important in the olivine-bearing dolerites than in calcite-bearing dolerites. On the other hand, the $\mathrm{Ba} / \mathrm{Sr}$ and $\mathrm{Y} / \mathrm{Nb}$ ratios are instead higher in the calcite-bearing dolerite and lower in the olivine-bearing dolerites.

The chondrite-normalized [28] spider diagram of REE (Figure 9) is not very different for the two groups of rocks and show enrichment in LREE. The patterns define two distinct groups representative of alkaline dolerites (G14S1, G14S10, G14S20) and tholeiitic dolerites (G14V1, G14V2, G14V3, G14V4, G14V5, G14V6). Olivinebearing dolerites have a positive $\mathrm{Nd}$ anomaly and the calcite-bearing dolerites have a negative $\mathrm{Nd}$ anomaly. In the olivine-bearing dolerites group, $\mathrm{Eu} / \mathrm{Eu}^{*}$ ratios range from 1.01 to 1.03 . In the calcite-bearing dolerite group, $\mathrm{Eu} / \mathrm{Eu}^{*}$ ratios fall between 0.89 and 1.00 .

The chondrite normalized multielement spider diagrams (Figure 10) of all the dolerites show a pronounced depletion in $\mathrm{Ba}, \mathrm{Th}$, and enrichment in $\mathrm{Rb}$. The olivinebearing dolerite is richer in $\mathrm{Nb}$, Ta with a positive anom- aly in $\mathrm{Sr}, \mathrm{Nb}, \mathrm{Ti}$ and a relative lower depletion in other elements. The calcite-bearing dolerites present negative more or less pronounced anomalies with $\mathrm{Sr}, \mathrm{Ti}, \mathrm{Ba}$ and Th.

\section{- Transition and base metals}

The intrusion of a late magmatic vein (body) in the metamorphic or magmatic crust is always accompanied by fluid circulations capable of precipitating metals and forming metalliferous deposits [29]. Analyses of heavy metals in the dolerites of Banefo-Mvoutsaha are reported in Table 1. In the studied dolerites, the $\mathrm{Cu}$ content varies from $42 \mathrm{ppm}$ to $69 \mathrm{ppm}$; its average is close to $\mathrm{Cu}$ contents of the crust (50 ppm). The content of $\mathrm{Ni}$ is less than that of the crust $(70 \mathrm{ppm})$ except that of sample G14S1 which is $76.7 \mathrm{ppm}$. In the calcite-bearing dolerite (except G14V6) Au is completely absent. $\mathrm{Zn}$ has content largely lower than that of the crust $(70 \mathrm{ppm})$. Concentrations of $\mathrm{As}, \mathrm{Cd}, \mathrm{Sb}, \mathrm{Bi}, \mathrm{Ag}, \mathrm{Hg}$ and $\mathrm{Se}$ are also extremely low. The spider diagram of primitive ultramafic nodules normalized transition metals [30] of studied dolerites (Figure 11) defines one pattern assemblage well constituted, parallel between them and largely fractioned. The transition metal diagram does not put in evidence the two groups of dolerites previously mentioned. The patterns show a negative anomalies in $\mathrm{Sc}, \mathrm{CrO}_{3}$ and $\mathrm{Ni}$; a positive anomalies in $\mathrm{TiO}_{2}, \mathrm{Fe}_{2} \mathrm{O}_{3}$ and $\mathrm{Cu}$.

The metals contents integrated in the correlation matrix (Table 3) have " $r$ " values comprised between 0.89 

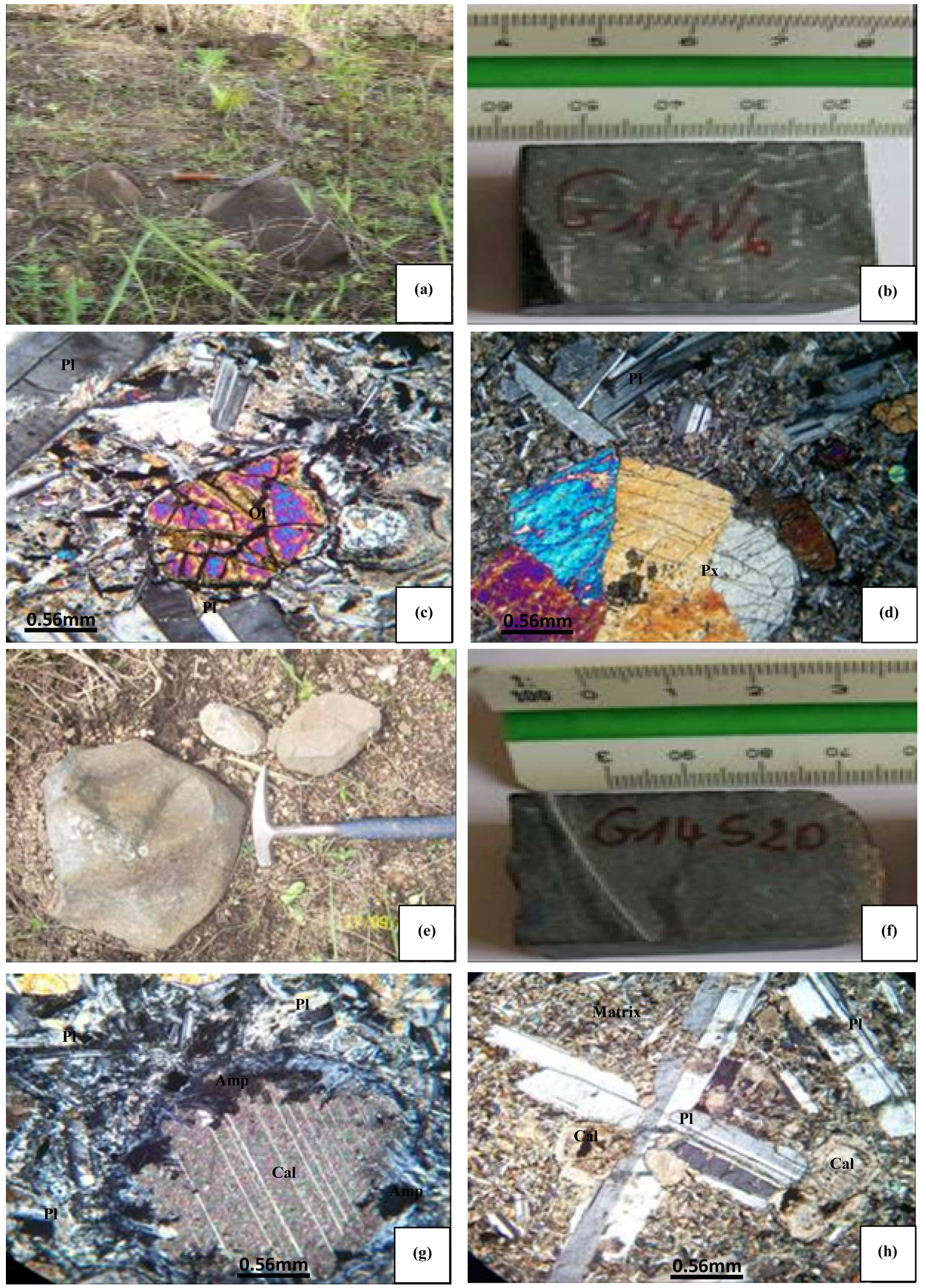

Figure 3. Field occurrences ((a) \& (e)), hand specimen view ((b) \& (f)) and microphotographs ((c), (d), (g) \& (h)) of studied dolerites. See text for detailed descriptions (PI: plagioclase; Cal: calcite; Ol: olivine; Px: pyroxene; Amp: amphibole). 


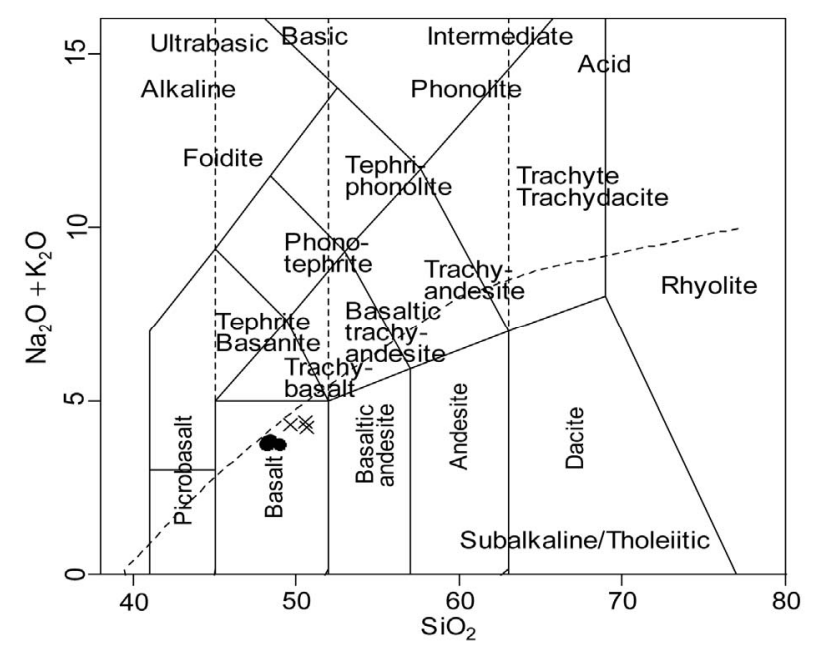

Figure 4. TAS classification diagram of Le Bas et al. [25] (symbols: black dots = olivine-bearing dolerite; cross = calcite-bearing dolerite).

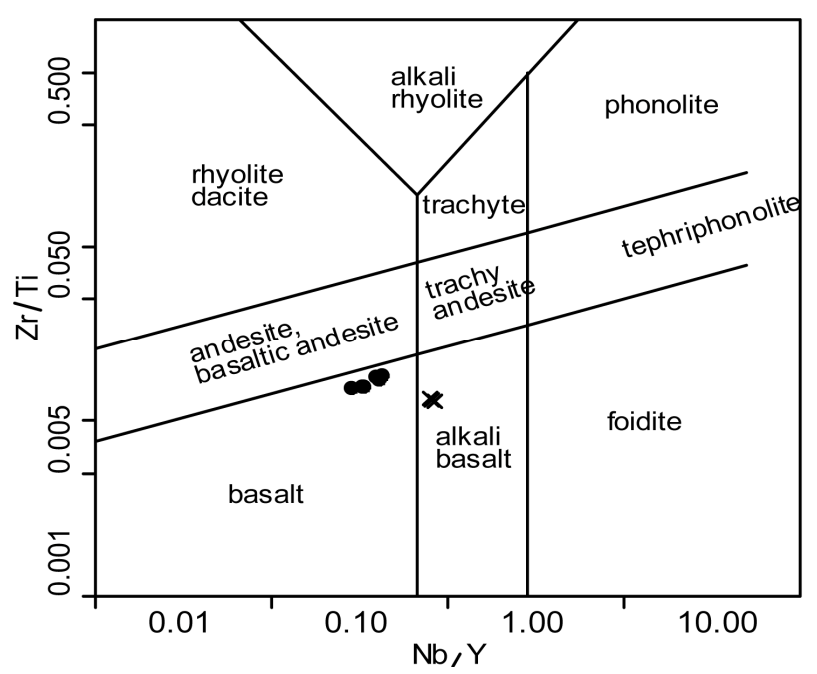

Figure 5. Nb/Y versus $\mathrm{Zr} / \mathrm{Ti}$ diagram of Pearce [26] showing the distribution of studied dolerites into two groups. For symbols, see Figure 4.

and 0.99. A strong positive correlation (0.73 to 0.99$)$ is observed for the Fe-Mn, Fe-Co, Fe-Pb, Fe-Zn, Fe-Tl, $\mathrm{Ti}-\mathrm{V}, \mathrm{Mn}-\mathrm{Co}, \mathrm{Mn}-\mathrm{Pb}, \mathrm{Mn}-\mathrm{Zn}$, Mn-Tl, Co-Pb, Co-Tl, $\mathrm{Pb}-\mathrm{Zn}$, and $\mathrm{Zn}-\mathrm{Tl}$ metals. $\mathrm{U}$ has negative correlation with all the elements of matrix and we note null correlation between Ag and other metals.

\section{Interpretation and Discussion}

The dolerites of Banefo-Mvoutsaha appear in a major shear zone in Cameroon and are lacking in all deformation features. Field observations make the dolerite dykes to be late to post tectonic formations. Contrasting features observe between the two types of dolerites on the basis of petrographic character namely, relative $\%$ of the matrix, size of minerals, secondary transformation of minerals, characteristic mineral (olivine/calcite) giving evidence of their crystallization duration and depth. The olivine-bearing dolerites have crystallized at a very important depth and at a time relatively longer than the time taken for calcite-bearing dolerite which crystallized at relatively shadow depth.

\subsection{Characterization and Source of Magma}

The high contents of LREE are characteristic of alkaline magmas while the low proportions are evidence of tholeiitic magmas. We can deduce that the alkaline basalts are originated from a magma coming from partial melting, contrary to tholeiitic basalts. The REE values (Tables 1 and 2), and the different REE ratios confirm the contrast of the two types of studied dolerites. The olivine-bearing dolerites have their values always more important than the calcite-bearing dolerite; this is a confirmation of their tholeiitic and alkaline characteristics [30]. The content of REE and the normalized ratios of REE increase with the degree of alkalinity.

The comparisons of the ratios of incompatible elements of dolerites with reference values in the crust [31], and of certain reservoirs of the mantle are presented in Table 3. These comparisons have permitted to put in evidence two distinct sources for the two types of the dolerites. The $\mathrm{Zr} / \mathrm{Nb}(12.75$ - 16.35), $\mathrm{Ba} / \mathrm{Nb}(25.15$ $51.95), \mathrm{La} / \mathrm{Nb}(1.18$ - 1.99), $\mathrm{Rb} / \mathrm{Nb}(4.76$ - 19.96), $\mathrm{Th} / \mathrm{Nb}$ (0.09 - 0.12), Ba/Th (266.43 - 557.27), Th/La (0.06 $0.08)$ and $\mathrm{Ba} / \mathrm{La}(20.85$ - 30.80) ratios for the calcite-bearing dolerite (tholeiitic affinity) are closed to those of a continental crust (crustal source). For the olivine-bearing dolerite (alkaline affinity), the values of the same ratios are respectively in the following order: 7.28 $7.58 ; 18.56-23.13 ; 0.95-0.99 ; 1.30-2.49 ; 0.10-0.11$; 180.67 - 237.86; $0.10-0.11 ; 19.22$ - 23.29. These values are closed to those of EM1 OIB with mantellic source, although the controversial source of the EM1 OIB brought up by the works of Mata et al. [32]. Thus the Banefo-Mvoutsaha dolerites are the result of two distinct sources which are crustal source for the calcite-bearing dolerites and mantellic source for the olivine bearing dolerite.

\subsection{Geotectonic Context}

The triangular diagram $\mathrm{Zr} / 4-2 \mathrm{Nb}-\mathrm{Y}$ of Meschede [33] which proposed the geotectonic context of basalts (Figure 12) defines the dolerites of Banefo-Mvoutsaha as intraplates basalts (AII-C Within-Plate Tholeiites) with calcite-bearing dolerites points belonging to field AII (Intraplate alkalin basalts) while the olivine-bearing dolerite points fall in the $\mathrm{C}$ field (Intraplate tholeiitic basalts). This geotectonic context is confirmed by a binary diagram $\mathrm{Zr} / \mathrm{y}-\mathrm{Zr}$ of geotectonic discrimination [34] of 

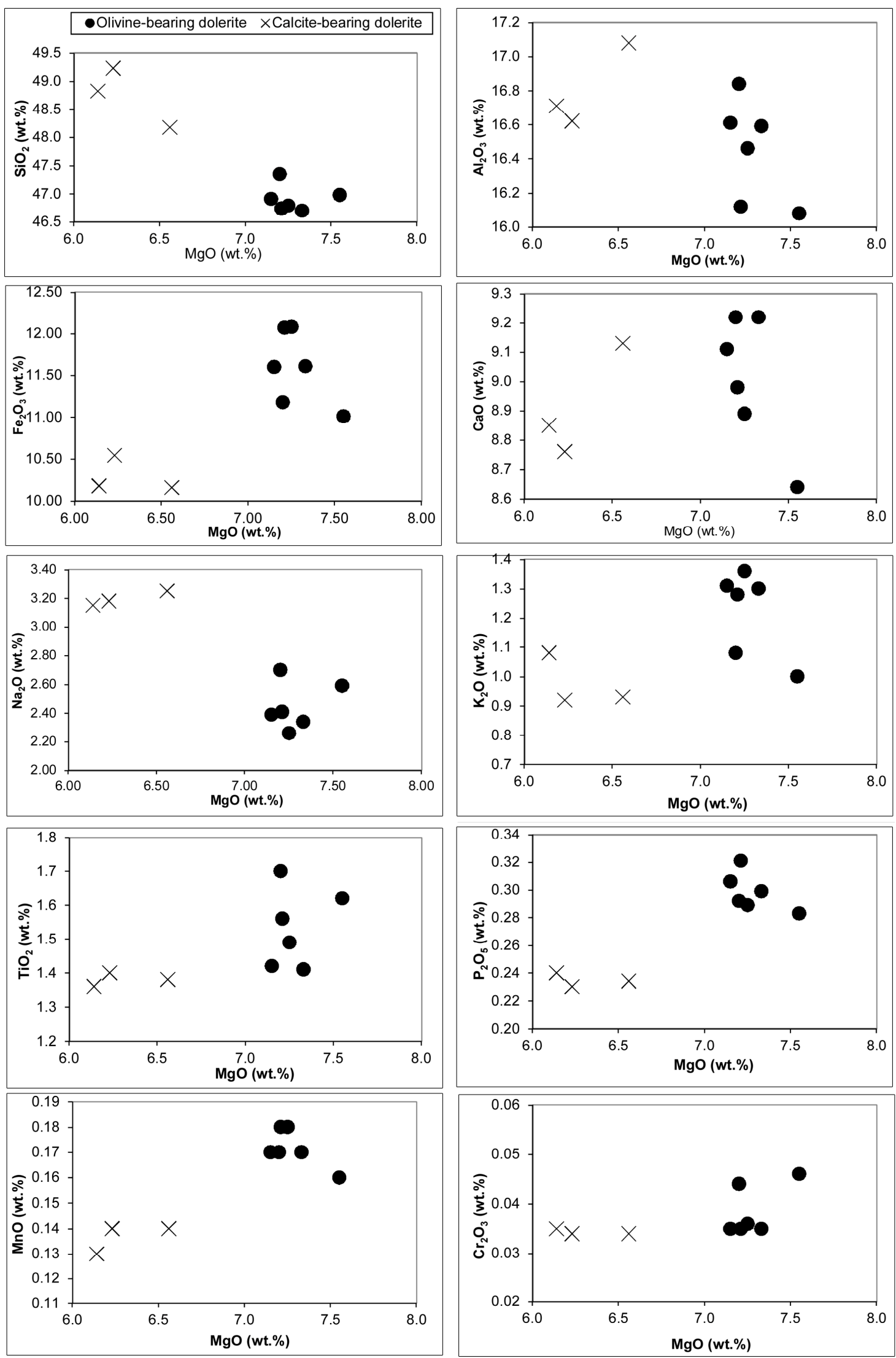

Figure 6. Harker diagrams of selected major elements versus MgO. 


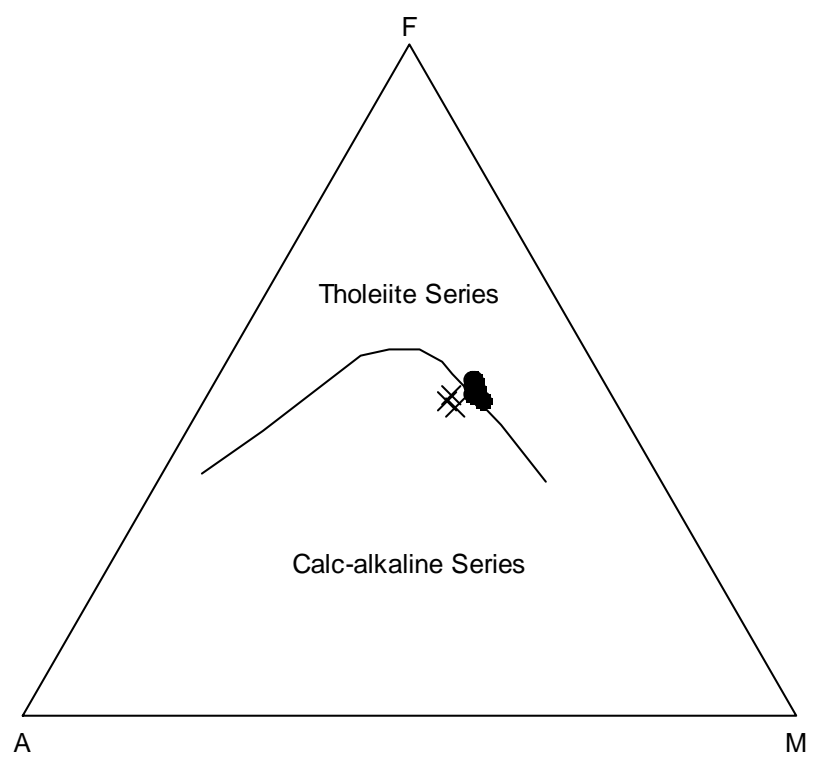

Figure 7. AFM diagram of Ivrine and Baragar [27] showing geochemical affinities of the Banefo-Mvoutsaha dolerites. Symbols as in Figure 6. basaltic rocks of a distinct geotectonic position; the studied dolerites are intraplate basalts (Figure 13).

\subsection{Metallogeny}

The metals contents of studied dolerites have values lower than the detection limits for some, another have values higher than the average concentration of the said elements in the crust. Unfortunately, all the metal contents are largely lower to the typical metalliferous deposit. However, for metal elements research, analysis is recommended in the lithological contacts and in the syntectonic granitoids of the study region which belongs to $\mathrm{CCC}$, an economic shear zone in its northern part.

\subsection{Comparison with the Dolerites of South Cameroon}

The $\mathrm{D}_{1}$ dolerites [8], presents a pattern (Figure 14) that differs from those of the studied dolerite by the negative anomaly more pronounced in $\mathrm{Nd}$ and an enrichment in HREE in relation to the olivine-bearing dolerites. The

Table 2. Compared average ratio data of some incompatible elements of the studied dolerites and dolerites from [8].

\begin{tabular}{|c|c|c|c|c|c|c|c|c|c|c|c|}
\hline \multirow[b]{2}{*}{ Rocks } & \multicolumn{9}{|c|}{ STUDIED DOLERITE } & \multicolumn{2}{|c|}{ DOLERITE FROM [8] } \\
\hline & \multicolumn{6}{|c|}{ Olivine-bearing dolerites (Tholeiitic) } & \multicolumn{3}{|c|}{ Calcite-bearing dolerites (Alkali) } & \multirow[b]{2}{*}{$D_{1}$ dolerite } & \multirow[b]{2}{*}{$\mathbf{D}_{2}$ dolerite } \\
\hline Sample No & G14V1 & G14V2 & G14V3 & G14V4 & G14V5 & G14V6 & G14S1 & G14S10 & G14S20 & & \\
\hline$(\mathrm{Y} / \mathrm{Nb}) \mathrm{N}$ & 0.43 & 0.61 & 0.53 & 0.54 & 0.41 & 0.45 & 0.22 & 0.22 & 0.21 & 1.46 & 0.32 \\
\hline$(\mathrm{Ce} / \mathrm{Yb}) \mathrm{N}$ & 4.09 & 3.52 & 3.89 & 3.96 & 4.03 & 3.98 & 6.25 & 6.52 & 6.41 & 1.41 & 5.69 \\
\hline$(\mathrm{Sm} / \mathrm{Yb}) \mathrm{N}$ & 2.61 & 2.44 & 2.61 & 2.69 & 2.63 & 2.66 & 3.30 & 3.29 & 3.21 & 1.56 & 3.07 \\
\hline$(\mathrm{Gd} / \mathrm{Yb}) \mathrm{N}$ & 1.64 & 1.64 & 1.69 & 1.77 & 1.61 & 1.63 & 1.86 & 1.95 & 1.86 & 1.02 & 1.62 \\
\hline$(\mathrm{Ba} / \mathrm{Sr}) \mathrm{N}$ & 2.89 & 1.80 & 1.59 & 2.04 & 1.69 & 1.65 & 0.99 & 1.24 & 1.23 & 0.97 & 2.45 \\
\hline$(\mathrm{Ba} / \mathrm{Rb}) \mathrm{N}$ & 0.55 & 0.11 & 0.10 & 0.12 & 0.10 & 0.22 & 0.72 & 0.47 & 0.74 & 0.37 & 0.46 \\
\hline $\mathrm{Ba} / \mathrm{Sr}$ & 1.69 & 1.05 & 0.93 & 1.19 & 0.99 & 0.96 & 0.58 & 0.72 & 0.72 & 0.56 & 1.43 \\
\hline $\mathrm{Ba} / \mathrm{Rb}$ & 10.91 & 2.24 & 2.01 & 2.27 & 2.00 & 4.38 & 14.26 & 9.30 & 14.50 & 7.22 & 9.16 \\
\hline $\mathrm{Ce} / \mathrm{Yb}$ & 11.87 & 10.20 & 11.29 & 11.49 & 11.67 & 11.54 & 18.13 & 18.90 & 18.59 & 4.08 & 16.49 \\
\hline $\mathrm{Sm} / \mathrm{Yb}$ & 1.83 & 1.71 & 1.83 & 1.88 & 1.84 & 1.87 & 2.31 & 2.31 & 2.24 & 1.09 & 2.15 \\
\hline $\mathrm{Nb} / \mathrm{Y}$ & 0.41 & 0.29 & 0.33 & 0.33 & 0.42 & 0.39 & 0.80 & 0.81 & 0.85 & 0.12 & 0.55 \\
\hline $\mathrm{Zr} / \mathrm{Nb}$ & 14.08 & 16.35 & 15.76 & 15.52 & 12.76 & 13.82 & 7.58 & 7.52 & 7.28 & 23.97 & 10.29 \\
\hline $\mathrm{Ba} / \mathrm{Nb}$ & 51.95 & 44.63 & 37.53 & 43.52 & 25.15 & 28.26 & 18.56 & 23.13 & 21.76 & 19.50 & 14.74 \\
\hline $\mathrm{La} / \mathrm{Nb}$ & 1.69 & 1.55 & 1.80 & 1.99 & 1.18 & 1.33 & 0.97 & 0.99 & 0.95 & 1.33 & 1.22 \\
\hline $\mathrm{Rb} / \mathrm{Nb}$ & 4.76 & 19.96 & 18.72 & 19.13 & 12.60 & 6.45 & 1.30 & 2.49 & 1.50 & 2.70 & 1.61 \\
\hline $\mathrm{Th} / \mathrm{Nb}$ & 0.09 & 0.11 & 0.11 & 0.12 & 0.09 & 0.11 & 0.10 & 0.10 & 0.11 & 0.13 & 0.17 \\
\hline $\mathrm{Ba} / \mathrm{Th}$ & 557.27 & 396.67 & 354.44 & 360.00 & 280.83 & 266.43 & 180.67 & 237.86 & 201.25 & 152.31 & 87.05 \\
\hline $\mathrm{Th} / \mathrm{La}$ & 0.06 & 0.07 & 0.06 & 0.06 & 0.08 & 0.08 & 0.11 & 0.10 & 0.11 & 0.10 & 0.14 \\
\hline $\mathrm{Ba} / \mathrm{La}$ & 30.80 & 28.79 & 20.85 & 21.88 & 21.33 & 21.31 & 19.22 & 23.29 & 23.00 & 14.64 & 12.06 \\
\hline $\mathrm{Na}_{2} \mathrm{O}+\mathrm{K}_{2} \mathrm{O}$ & 3.59 & 3.70 & 3.64 & 3.62 & 3.69 & 3.78 & 4.18 & 4.23 & 4.10 & - & - \\
\hline $\mathrm{K}_{2} \mathrm{O} / \mathrm{Na}_{2} \mathrm{O}$ & 0.39 & 0.55 & 0.56 & 0.60 & 0.53 & 0.40 & 0.29 & 0.34 & 0.29 & - & - \\
\hline
\end{tabular}



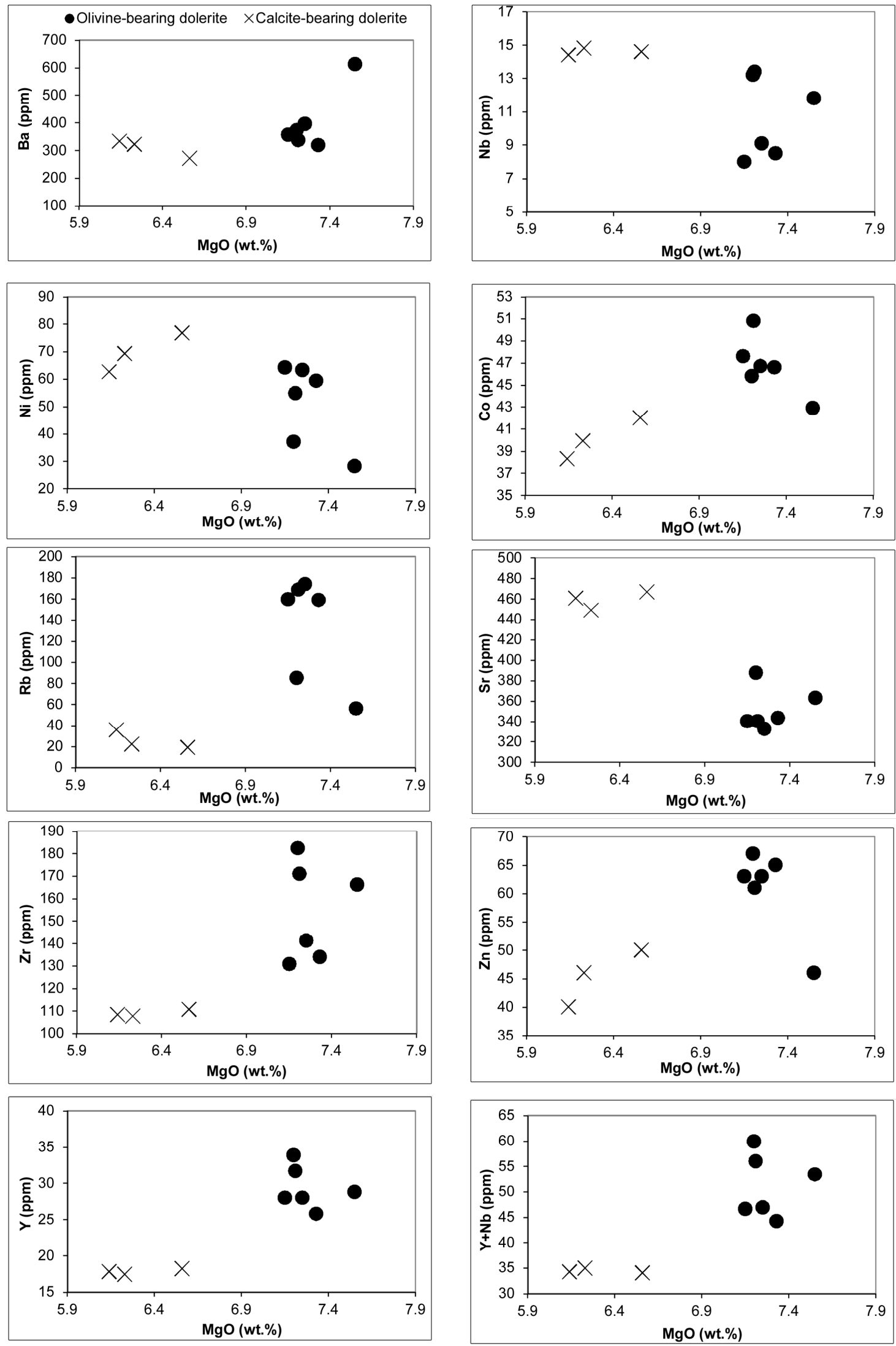

Figure 8. Harker diagrams of selected trace elements versus MgO. 


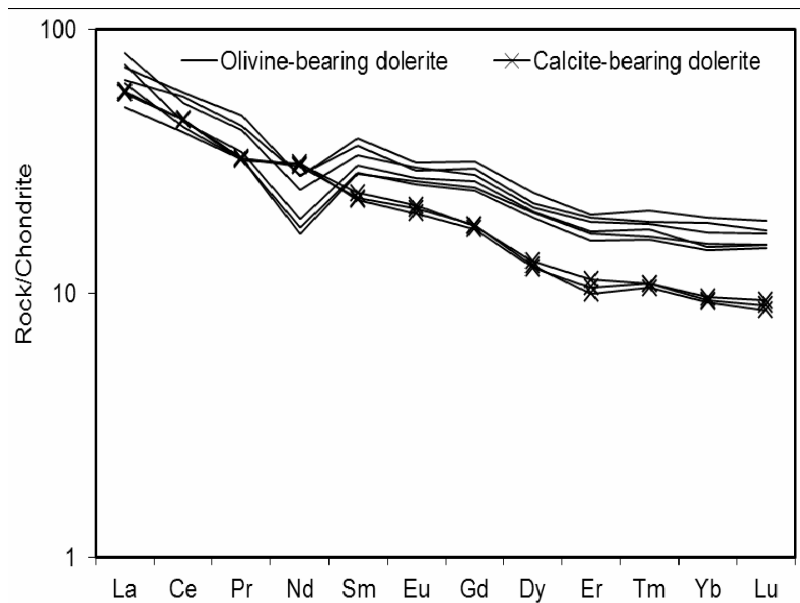

Figure 9. Chondrite-normalised REE patterns (the normalising values are from Evensen et al. [28]) for studied dolerites.

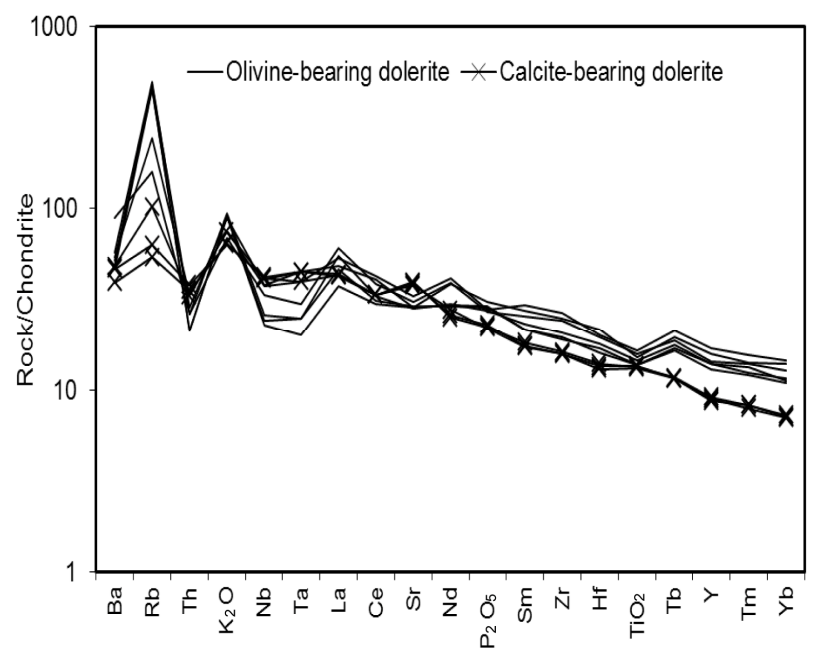

Figure 10. Chondrite-normalised multi-element patterns (the normalising values are from Evensen et al. [28]) for studied dolerites.

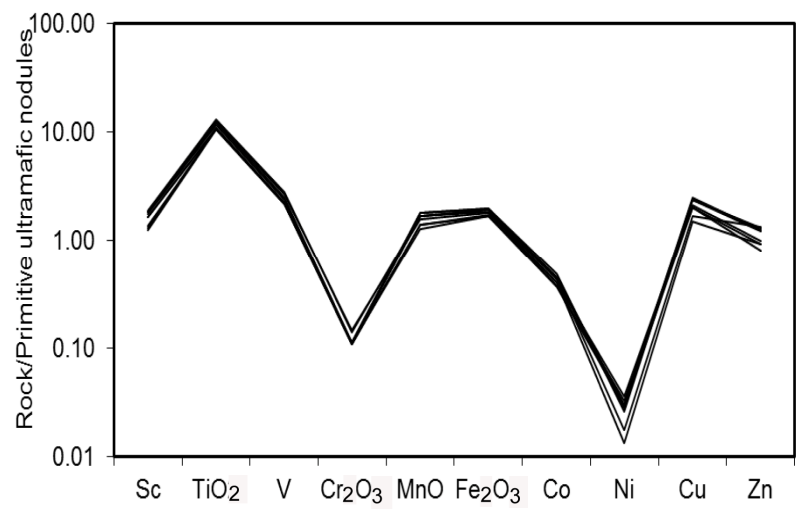

Figure 11. Primitive ultramafic nodules-normalised REE patterns (the values used in normalisation are from Jagoutz et al. [30]) of selected transitional metals for studied dolerites.

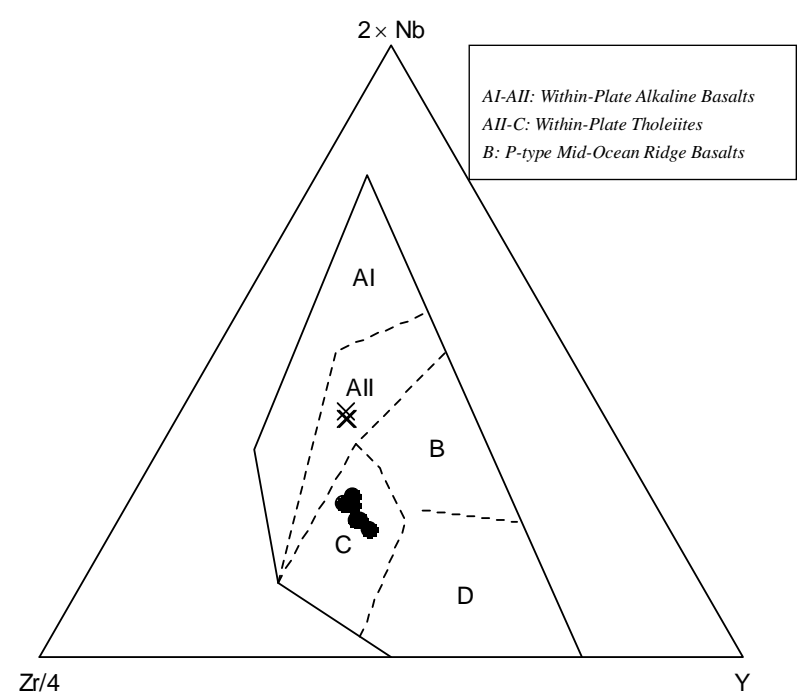

Figure 12. Zr/4-2Nb-Y ternary diagram of Meschede [33] showing the geotectonic context of Bafoussam dolerites.

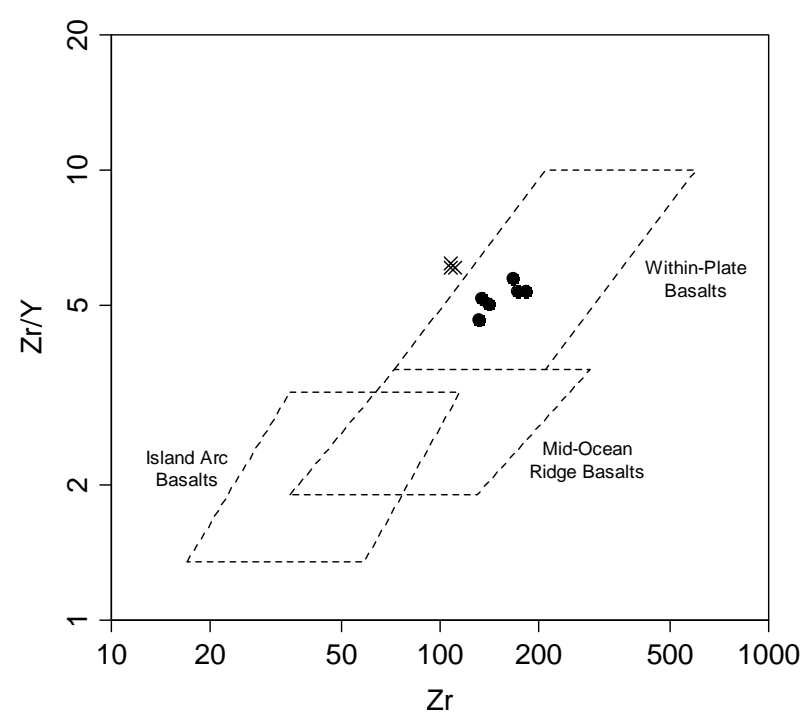

Figure 13. Geotectonic discrimination diagram of basaltic rocks [34] showing the localisation of the studied dolerites in the field of within-plate basalts.

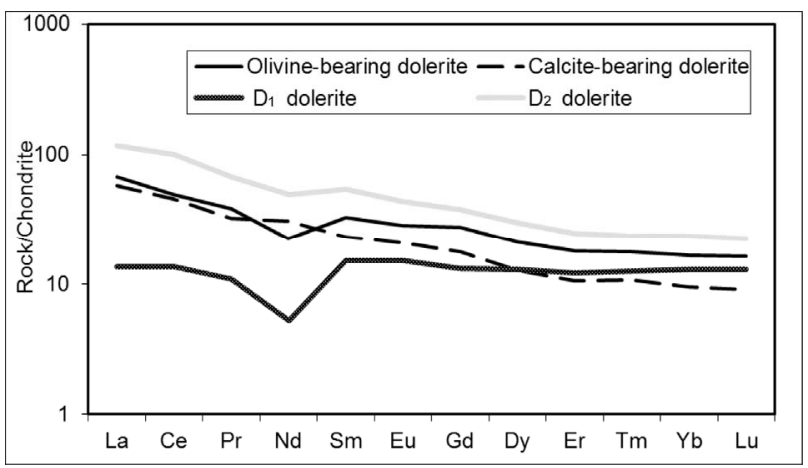

Figure 14. Chondrite-normalized REE comparison patterns for Bafoussam dolerites, and $D_{1} \& D_{2}$ dolerites from [8]. 
Table 3. Correlation coefficient matrix for selected metals elements.

\begin{tabular}{|c|c|c|c|c|c|c|c|c|c|c|c|c|c|c|c|}
\hline & $\mathrm{Fe}$ & $\mathrm{Ti}$ & $\mathrm{Mn}$ & Co & $\mathrm{U}$ & V & Mo & $\mathrm{Cu}$ & $\mathrm{Pb}$ & $\mathrm{Zn}$ & $\mathrm{Ni}$ & $\mathrm{Cd}$ & $\mathrm{Ag}$ & $\mathrm{Au}$ & $\mathrm{Tl}$ \\
\hline $\mathrm{Fe}$ & 1.00 & & & & & & & & & & & & & & \\
\hline $\mathrm{Ti}$ & 0.39 & 1.00 & & & & & & & & & & & & & \\
\hline $\mathrm{Mn}$ & 0.96 & 0.55 & 1.00 & & & & & & & & & & & & \\
\hline Co & 0.91 & 0.42 & 0.94 & 1.00 & & & & & & & & & & & \\
\hline $\mathrm{U}$ & -0.71 & -0.16 & -0.71 & -0.62 & 1.00 & & & & & & & & & & \\
\hline $\mathrm{V}$ & 0.36 & 0.99 & 0.52 & 0.37 & -0.13 & 1.00 & & & & & & & & & \\
\hline Mo & -0.26 & -0.64 & -0.29 & -0.18 & -0.02 & -0.66 & 1.00 & & & & & & & & \\
\hline $\mathrm{Cu}$ & 0.51 & -0.53 & 0.36 & 0.50 & -0.33 & -0.56 & 0.33 & 1.00 & & & & & & & \\
\hline $\mathrm{Pb}$ & 0.78 & 0.00 & 0.74 & 0.73 & -0.63 & -0.06 & 0.09 & 0.67 & 1.00 & & & & & & \\
\hline $\mathrm{Zn}$ & 0.79 & 0.39 & 0.87 & 0.86 & -0.63 & 0.33 & -0.24 & 0.44 & 0.83 & 1.00 & & & & & \\
\hline $\mathrm{Ni}$ & -0.23 & -0.87 & -0.36 & -0.19 & 0.28 & -0.89 & 0.59 & 0.69 & 0.19 & -0.12 & 1.00 & & & & \\
\hline $\mathrm{Cd}$ & 0.68 & 0.32 & 0.63 & 0.59 & -0.52 & 0.33 & -0.08 & 0.25 & 0.19 & 0.24 & -0.29 & 1.00 & & & \\
\hline $\mathrm{Ag}$ & 0.00 & 0.00 & 0.00 & 0.00 & 0.00 & 0.00 & 0.00 & 0.00 & 0.00 & 0.00 & 0.00 & 0.00 & 1.00 & & \\
\hline $\mathrm{Au}$ & 0.34 & 0.34 & 0.36 & 0.32 & -0.60 & 0.35 & 0.06 & -0.21 & 0.01 & 0.01 & -0.61 & 0.61 & 0.00 & 1.00 & \\
\hline $\mathrm{Tl}$ & 0.89 & 0.53 & 0.93 & 0.78 & -0.81 & 0.51 & -0.31 & 0.26 & 0.66 & 0.81 & -0.43 & 0.60 & 0.00 & 0.36 & 1.00 \\
\hline
\end{tabular}

concentrations of all the REE in the $\mathrm{D}_{1}$ dolerites remain lower to those of calcite-bearing dolerite. The $\mathrm{D}_{2}$ dolerites have a pattern subparallel to the olivine-bearing dolerites pattern and present a concentration of all the REE higher than those of Banefo-Mvoutsaha.

The multi-element pattern (Figure 15) of $\mathrm{D}_{1}$ dolerites differs from the pattern of the studied dolerites by a positive anomaly in $\mathrm{P}_{2} \mathrm{O}_{5}$ and a higher concentration in $\mathrm{Y}$, $\mathrm{Tm}$ and $\mathrm{Yb}$ in olivine-bearing dolerites, but these concentrations remain lower than those of calcite-bearing dolerites. The multi-element pattern of the $\mathrm{D}_{2}$ dolerites has low $\mathrm{Rb}$ content and shows a negative anomaly more pronounced in $\mathrm{Sr}$ than the dolerites of Banefo-Mvoutsaha.

\section{Conclusion}

The Banefo-Mvoutsaha dolerites are late to post tectonic basic dykes showing doleritic texture. Based on the mineralogical composition, two distinct petrographic types are identified: the olivine-bearing dolerites which are dark green, with less amount of matrix $(\sim 40 \%)$ and the calcite-bearing dolerites which have grayish green color, rich in ground mass $(\sim 60 \%)$. Geochemical analysis confirms the two types of dolerites. The calcite-bearing dolerites present the characteristic of alkaline basalts while the olivine-bearing dolerites present the characteristics of tholeiitic basalts; their geotectonic context inferred to be intraplate. The studied dolerites are less differentiated $\left(1<\mathrm{FeO}^{\mathrm{t}} / \mathrm{MgO}<2\right)$; and the contrast between the two types is probably due to a diverse source: crustal source for calcite-bearing dolerites and mantle source for olivine-bearing dolerites. The two types of dolerites of

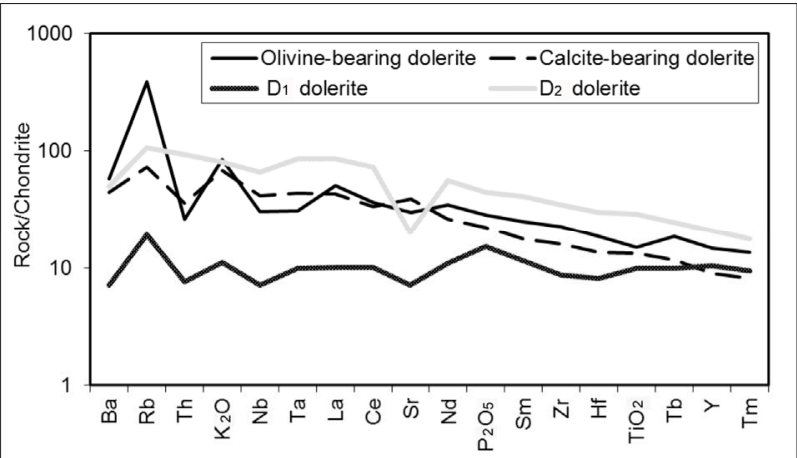

Figure 15. Chondrite-normalized multi-element comparison patterns for Bafoussam dolerites, and $D_{1} \& D_{2}$ dolerites from [8].

the Banefo-Mvoutsaha area represent the evolution of a subalkaline magma following a calco-alkaline series (alkaline dolerites) and the tholeiitic series (tholeitiic dolerite). The magmas from which the dolerite originated were accompanied during its emplacements by the hydrothermal fluids circulation which drained few metals. The concentrations of those metals have not been able to constitute a metalliferous deposit within this part of major shear zone. Comparing with the ancient $\mathrm{D}_{1}$ and $\mathrm{D}_{2}$ dolerite of Vicat et al. [8], it's resorted that the studied dolerites are different on chemical component and consequently have different characteristics.

\section{Acknowledgements}

The authors wish to thank the anonymous reviewers for the comments and suggestions that permitted a substantial improvement of the original manuscript. 


\section{REFERENCES}

[1] J. G. Fitton, "Active versus Rifting: Evidence from the West African System," Tectonophysics, Vol. 94, No. 1-4, 1983, pp. 473-481. http://dx.doi.org/10.1016/0040-1951(83)90030-6

[2] E. Njonfang, "Contribution à L'étude de la Relation entre la 'Ligne du Cameroun' et la Direction de l'Adamawa: 1Pétrologie, Géochimie et Structure des Granitoïdes Panafricains de la Zone de Cisaillement Foumban-Bankim (Ouest-Cameroun et Adamawa). 2-Pétrologie et Géochimie des Formations Magmatiques Tertiaires Associées," Thèse de Doctorat d'Etat, University of Yaoundé I, Yaoundé, 1998, p. 379.

[3] C. Moreau, T. M. Regnoult, B. Déruelle and B. Robineau, "A New Tectonic Model for Cameroon Line, Central Africa," Tectonophysics, Vol. 139, 1987, pp. 317-334.

[4] R. Guiraud, R. M. Binks, C. S. Fairhe Szabo, J. D. Fairhead and M. Wilson, "Chronology and Geodynamic Setting of Cretaceous-Cenozoic Rifting in West and Central Africa," Tectonophysics, Vol. 213, No. 1-2, 1992, pp. 227234. http://dx.doi.org/10.1016/0040-1951(92)90260-D

[5] E. L. Tanko Njiosseu, J. P. Nzenti, T. Njanko, B. Kapajika and A. Nédelec, "New U-Pb Zircon Ages from Tonga (Cameroon): Coexisting Eburnean-Transamazonian (2.1 Ga) and Pan-African (0.6 Ga) Imprints," Comptes Rendus Géosciences, Vol. 337, No. 16, 2005, pp. 551-562. http://dx.doi.org/10.1016/j.crte.2005.02.005

[6] J. P. Nzenti, E. L. Tanko Njiosseu and A. Nzina Nchare, "The Metamorphic Evolution of the Palaeoproterozoic High Grade Banyo Gneisses (Adamawa, Cameroon, Central Africa)," Journal of the Cameroon Academy of Sciences, Vol. 7, No. 2, 2007, pp. 95-109.

[7] M. L. Djouka-Fonkwe, B. Schulz, J. P. Tchouankoué and C. Nzolang, "Geochemistry of the Bafoussam Pan-African I- and S-type Granitoids in Western Cameroon," Journal of African Earth Sciences, Vol. 50, No. 2-3, 2008, pp. 148-167.

http://dx.doi.org/10.1016/j.jafrearsci.2007.09.015

[8] J. P. Vicat, A. Pouclet and E. Nsifa, "Les Dolérites du Groupe du Ntem (Sud Cameroun) et des Régions Voisines (Centrafrique, Gabon, Congo, Bas Zaïre): Caractéristiques Géochimiques et Place dans L'évolution du Craton du Congo au Protérozoïque,” In: J. P. Vicat and P. Bilong, Eds., Géologie et Environnements au Cameroun, Collection GEOCAM, 1998, pp. 305-324.

[9] J. P. Vicat, A. Moloto, G. R. Kenguemba and A. Pouclet, "Les Granitoïdes de la Couverture Protérozoïque de la Bordure nord du Craton du Congo (sud-est du Cameroun et Sud-Ouest de la République Centrafricaine), Témoins d'une Activité Magmatique Post-Kibarienne à PréPanafricaine," Comptes Rendus de l'Académie des Sciences Paris, Sciences de la Terre et des Planètes, Vol. 332, No. 4, 2001, pp. 235-242.

[10] J. P. Tchouankoue, N. A. Simeni Wambo, A. Kagou Dongmo and G. Wörner, "Petrology, Geochemistry, and Geodynamic Implications of Basaltic Dyke Swarms from the Southern Continental Part of the Cameroon Volcanic Line, Central Africa," The Open Geology Journal, Vol. 6, No. 1, 2012, pp. 72-84. http://dx.doi.org/10.2174/1874262901206010072

[11] J. G. Fitton, "The Cameroon Line-West Africa: A Comparison between Oceanic and Continental Alkaline Volcanism," Geology Society, Special Publication, Vol. 30, 1987, pp. 273-291. http://dx.doi.org/10.1144/GSL.SP.1987.030.01.13

[12] D. C. Lee, A. N. Halliday, J. G. Fitton and G. Poli, "Isotopic Variation with Distance and Time in the Volcanic Islands of the Cameroon Line: Evidence for a Mantle Plume Origin," Earth Planetary Science Letter, Vol. 123, 1994, pp. 119-138.

http://dx.doi.org/10.1016/0012-821X(94)90262-3

[13] B. Déruelle, C. Moreau, C. Nkoumbou, R. Kambou, J. Lissom, E. Njonfang, R. T. Ghogomu and A. Nono, "The Cameroon Line: A Review," In: A. B. Kampuru and R. T. Lubala, Eds., Magmatism in Extensional Structural Settings, The Phanerozoic African Plate, Springer, Berlin, 1991, pp. 274-328.

http://dx.doi.org/10.1007/978-3-642-73966-8 12

[14] B. Déruelle, I. Ngounouno and D. Demaiffe, "The Cameroon Hot Line (CHL): A Unique Example of Active Alkaline Intraplate Structure in Both Oceanic and Continental Lithospheres," Comptes Rendus Geosciences, Vol. 339, No. 9, 2007, pp. 589-600.

http://dx.doi.org/10.1016/j.crte.2007.07.007

[15] C. E. Suh, R. S. J. Sparks, J. G. Fitton, S. N. Ayonghe, C. Annen, R. Nana and A. Luckman, "The 1999 and 2000 Eruptions of Mount Cameroon: Eruption Behaviour and Petrochemistry of Lava," Bulletin of Volcanology, Vol. 65, No. 4, 2003, pp. 267-281. http://dx.doi.org/10.1007/s00445-002-0257-7

[16] J. P. Nzenti, V. Ngako, R. Kambou, J. Penaye, J. Bassahak and O. U. Njel, "Structures Régionales de la Chaîne Panafricaine du Nord-Cameroun," Comptes Rendus de L'académie des Sciences, Paris, Vol. 315, No. 2, 1992, pp. 209-215.

[17] J. P. Nzenti, P. Barbey, J. M. Bertrand and J. Macaudière, "La Chaîne Panafricaine au Cameroun: Cherchons Suture et Modèle!" 15th Edition, Réunion des Sciences de la Terre, Nancy, 1994.

[18] J. P. Nzenti, Njanko, E. L. T. Tanko Njiosseu, F. M. Tchoua, "Les Domaines Granulitiques de la Chaine Panafricaine Nord-Equatoriale au Cameroun," In: J. P. Vicat and P. Bilong, Eds., Géologie et Environnements au Cameroun, Collection GEOCAM I, 1998, pp. 255-264.

[19] V. Ngako, "Les Déformations Continentales Panafricaines en Afrique Centrale: Résultat d'un Poinçonnement de Type Himalayen," Thèse de Doctorat d'Etat, University of Yaoundé I, Yaoundé, 1999, p. 301.

[20] V. Ngako, P. Affaton, J. M. Nnange and T. Njanko, "PanAfrican Tectonic Evolution in Central and Southern Cameroon: Transpression and Transtension during Sinistral Shear Movements," Journal of African Earth Sciences, Vol. 36, No. 3, 2003, pp. 207-214. http://dx.doi.org/10.1016/S0899-5362(03)00023-X

[21] C. Nzolang, H. Kagami, J. P. Nzenti and F. Holtz, "Geochemistry and Preliminary Sr-Nd Isotopic Data on the Neoproterozoïc Granotoïds from the Bantoum Area, West Cameroon: Evidence for a Derivation from a Paleopro- 
terozoic to Archean Crust," Polar Geosciences, Vol. 16, 2003, pp. 196-226.

[22] S. F. Toteu, J. Penaye and Y. P. Djomani, "Geodynamic Evolution of the Pan-African Belt in Central Africa with Special Reference to Cameroon," Canadian Journal of Earth Sciences, Vol. 41, No. 1, 2004, pp. 73-85. http://dx.doi.org/10.1139/e03-079

[23] T. Ngnotue, S. Ganno, J. P. Nzenti, B. Schulz, D. Tchaptchet Tchato and E. Suh Cheo, "Geochemistry and Geochronology of Peraluminous High-K Granitic Leucosomes of Yaoundé Series (Cameroon): Evidence for a unique Pan-African Magmatism and Melting Event in North Equatorial Fold Belt," International Journal of Geosciences, Vol. 3, No. 3, 2012, pp. 525-548. http://dx.doi.org/10.4236/ijg.2012.33055

[24] G. D. Kouankap Nono, J. P. Nzenti, C. E. Suh and S. Ganno, "Geochemistry of Ferriferous, High-K Calc-Alkaline Granitoids from Banefo-Mvoutsaha Massif (NE Bafoussam), Central Domain of the Pan-African Fold Belt, Cameroon," The Open Geology Journal, Vol. 4, No. 1, 2010, pp. 15-28. http://dx.doi.org/10.2174/1874262901004010015

[25] M. J. Le Bas, R. W. Le Maître, A. Streckeisen and B. Zanettin, "A Chemical Classification of Volcanic Rocks Based on the Total Alkali-Silica Diagram," Journal of Petrology, Vol. 27, No. 3, 1986, pp. 745-750. http://dx.doi.org/10.1093/petrology/27.3.745

[26] J. A. Pearce, "A User's Guide to Basalt Discrimination Diagrams," In: D. A. Wyman, Ed., Trace Elements Geochemistry of Volcanic Rocks: Applications for Massive sulphide Exploration, Geological Association of Canada, Short Course Notes 12, 1996, pp. 79-113.

[27] T. M. Irvine and W. R. Baragar, "A Guide to the Chemical Classification of Common Volcanic Rocks," Canadian Journal of Earth Science, Vol. 8, No. 5, 1971, pp.
523-548. http://dx.doi.org/10.1139/e71-055

[28] N. M. Evensen, M. J. Hamilton and R. J. O’Nions, "Rare Earth Abundances in Chondritic Meteorites," Geochemical and Cosmochemical Acta, Vol. 42, 1978, pp. 11991212. http://dx.doi.org/10.1016/0016-7037(78)90114-X

[29] B. W. D. Yardley, "Metal Concentrations in Crustal Fluids and Their Relationship to Ore Formation," Economic Geology, Vol. 100, No. 4, 2005, pp. 613-632.

[30] E. Jagoutz, H. Palme, H. Baddenhaussen, K. Blum, M. Cendales, G. Dreibus, B. Spohel, V. Lorenz and H. Wanke, "The Abundances of Major, Minor and Traces Elements in the Earth's Mantle as Derived from Primitive Ultramafic Nodules," Lunar and Planetary Science Conference No. 10, Geochemical Acta, Suppl. 11, 1979, pp. 20312050 .

[31] A. Zindler and S. R. Hart, "Chemical Geodynamics," Annual Review of Earth and Planetary Sciences, Vol. 14, 1986, pp. 493-571. http://dx.doi.org/10.1146/annurev.ea.14.050186.002425

[32] J. Mata, R. Kerrich, N. D. MacRae and T. W. Wu, "Elemental and Isotopic ( $\mathrm{Sr}, \mathrm{Nd}$ and $\mathrm{Pb}$ ) Characteristics of Madeira Island Basalts; Evidence for a Composite HIMUEM1 Plume Fertilizing Lithosphere," Canadian Journal of Earth Sciences, Vol. 35, 1998, pp. 980-997. http://dx.doi.org/10.1139/e98-046

[33] M. Meschede, "A Method of Discrimination between Different Types of Mid-Ocean Ridge Basalts and Continental Tholeiites with the Nb-Zr-Y Diagram," Chemical Geology, Vol. 56, No. 3-4, 1986, pp. 207-218. http://dx.doi.org/10.1016/0009-2541(86)90004-5

[34] J. A. Pearce and M. J. Norry, "Petrogenetic Implications of Ti, Zr, Y and Nb Variations in Volcanic Rocks," Contribution to Mineralogy and Petrology, Vol. 69, No. 1, 1979, pp. 33-47. http://dx.doi.org/10.1007/BF00375192 